\title{
The Rise of Counterrevolutionary Anti-Fascism in the United States from the Munich Conference to the Fall of France
}

\author{
Michael SEIDMAN \\ University of North Carolina Wilmington (USA) \\ orcid.org/0000-0002-4121-9848
}

Submission date: 10 June 2019 | Accepted date: 25 June 2019 | Published in: 15 Dec. 2019

Recommended citation: Seidman, Michael. 2019. "The Rise of Counterrevolutionary Anti-Fascism in the United States from the Munich Conference to the Fall of France". Dictatorships \& Democracies. Journal of History and Culture 7: 37-68. doi: https://dx.doi.org/10.7238/dd.voi7.3163.

Abstract: Anti-fascism makes working or fighting against fscism the top priority, and two basic types of anti-fascism emerged in Europe and North America from 1936 to 1945. The first was revolutionary; the second was conservative and even counterrevolutionary. From the Munich Agreement to the fall of France, and in the face of strong isolationist opposition, US counterrevolutionary anti-fascists-who are usually labeled "interventionists" in the historiography—articulated to an increasingly sympathetic public how fascist regimes jeopardized the United States' national security and way of life.

Keywords: anti-fascism, fascism, counterrevolutionary, revolutionary, World War II, United States (US), United Kingdom (UK), France, Roosevelt, Hitler, Jews, Christian, antiSemitism, isolationism, interventionism, Versailles, Munich

\section{Introduction}

Two basic types of anti-fascism emerged in Europe and North America from 1936 to 1945 . The first was the revolutionary anti-fascism promoted during the Spanish Civil War (1936-1939) and often dominant in countries, like Spain, with a weak bourgeoisie. Revolutionary anti-fascism identified capitalism and fascism and was uninterested in the considerable differences between Spanish, Italian, and German fascisms or between fascist and authoritarian regimes. The revolutionary anti-fascism of the Spanish conflict encouraged the end of pacifism among sectors of the left, but because of the Spanish Republic's disrespect for private property and its violent anticlericalism it did not prefigure - as many have argued - the antifascist alliance of World War II. Revolutionary anti-fascism resurfaced in 
Eastern Europe with the Hitler-Stalin pact (August 1939-June 1941), when it influenced the behavior of the American, British, and French Communist parties, which condemned the war as "imperialist" and treated all belligerents as real or potential "fascists". Like the appeasers in the 1930s, Communists in this period generally preferred pacifism to anti-fascism. Revolutionary anti-fascism also revived at the end of World War II when it became the official ideology of the incipient Soviet bloc and helped to lend it legitimacy against a new adversary—-the "fascist" West. As in the Republican zone during the Spanish Civil War, revolutionary anti-fascism in the new "popular democracies" labeled as "fascist" any opposition-including workers' strikes, revolts, and refusals to work-against Communist-supported governments.

The second type of anti-fascism was conservative and even counterrevolutionary. The lack of reflection on this sort of anti-fascism mirrors the general historiographical neglect of counterrevolutions. The few important exceptions have neglected to study conservative anti-fascism as a variety of counterrevolution. The classic study described types of counterrevolutions but associated all of them with "monopolistic control of state and government by a new political elite", a definition which hardly describes the transatlantic counterrevolutions after World War II (Mayer 1971, 115; see also Meisel 1966). A recent text asserted that in countries where fascism failed to become a mass movement "mainstream conservatives" supposedly rejected "the main tenets of the French Revolution ... [and] did not feel sufficiently threatened in the 1930 s to call on fascism for help" (Paxton 2004, 22, 71, 114, 219). Yet the US, UK, and France all experienced "a sense of overwhelming crisis" which many felt "beyond the reach of traditional solutions", but fascists never came close to taking power in these nations. Furthermore, "mainstream conservatives" actively created and participated in French and British anti-fascist movements. Instead of desiring "to keep the masses out of politics", counterrevolutionary antifascists - such as Winston Churchill and Charles de Gaulle-wanted to win the masses over to conservative anti-fascism. Anti-fascism in Western Europe and North America was not merely defensive and passive but often more dynamic than fascism itself and would outlast its enemy in a war of attrition. In the US, during the administration of President 
Franklin D. Roosevelt, liberals and conservatives formed an increasingly popular and effective anti-fascist coalition between the Munich Conference and the fall of France.

\section{US perceptions of Fascism}

Some positive coverage of the Third Reich on a productivist and antiCommunist basis initially characterized American mainstream publications such as Time, Reader's Digest, and the Saturday Evening Post. The perception of Germany and the Germans as a land and people much like (white) America was a barrier to understanding the Nazi phenomenon. Many Americans viewed the "productive, thrifty and reliable [and clean] Germans" as reflecting their own virtues (Moore 2010, 18, 105). Given their own potent work ethic, Americans admired a similar legacy in Germany. This common appreciation of labor helped to foster sympathetic treatment and even the whitewashing of German atrocities. Likewise, the rapid decline of German unemployment bolstered the Reich's reputation in the US. Furthermore, as in Europe, anti-Communists often favored the Nazi state as a barrier to Communism and the Soviet Union. Familiar antiSemitism — but not European political anti-Semitism — among up to half of the American population reinforced philo-Germanism among large sectors of the public.

Yet despite a certain shared Judeophobia and racism, Nazism was never popular in the US. In contrast to Mussolini, whose negative image took some time to develop, Hitler immediately aroused grave suspicion in the American media. The Duce had cooperated diplomatically by endorsing the Young and Dawes plans of the 1920s, which rescheduled Versailles reparations. In addition, Mussolini was open to Roosevelt's proposals on disarmament in the 1930s; in contrast, the Führer was consistently obstructionist. In the US, the Nazi seizure of power bolstered anti-fascism more than it did fascism. The brutal aggressions of the party's paramilitary units, the early boycotts of Jews, and the Röhm purge (the Night of the Long Knives) of 1934 brought Nazism into disrepute. Many journalists, politicians, clergymen, and trade unionists denounced the Hitler regime. They saw that Nazism envisaged a "totalitarian state" which would 
ruthlessly suppress established American "political, religious, and even scientific freedom". Hitlerism had transferred "the doctrine of Divine Right from king to race" (Wise 1934a, xii; Tuttle 1934, 253).

Like those in Britain and France, American anti-fascist analyses generally remained captive by the past. Fascism was interpreted as slavery and regression to barbarism. The "pagan, pre-Christian level" of Nazism led to the "re-subjection of women". "This society of heroes and henchmen, of leaders and blindly obedient warriors is to be an exclusively male society". Its antifeminism contributed to the construction of "a warrior society committed to national glory". Nazi and Fascist attempts to return women to purely domestic tasks appalled several American commentators. Alice Hamilton, the first woman to be appointed to the Harvard faculty, discerned that "no woman of any prominence in the woman's movement is connected with the Nazi regime". She criticized the regime for making the "state all-important, not the individual child". Hamilton linked the "enslavement of women" to the Nazi explanation that "sex equality and sex freedom" were "Jewish doctrines". The Nazis limited female enrollment in universities to 10 percent and thus reduced the number of women in higher education from between twenty-three thousand and thirty thousand to fifteen thousand. In the regime's "battle against unemployment" men were favored over women, who were pressured to leave their jobs if the husband, father, or brother was a wage earner. The regime hoped that women would eventually be employed "only in womanly work, domestic service ... and welfare work". "Hitler's habit of arresting innocent women for alleged crimes of their husbands and brothers" disturbed British and American feminists (Lewisohn 1934; Hastings 2011, 11; Strachan 1997, 375-376; Hamilton 1934, 78, 83; Humann 2014, 75; Gottlieb 2010, 108).

By the mid-1930s the American public generally condemned dictatorships, and the use of the word "dictator" became as unpopular as that of "fascist". It was symptomatic that negative attitudes toward Mussolini and Hitler led to automaker Studebaker's 1937 decision to stop producing the vehicle named Dictator. In this context, on October 5, 1937, Roosevelt made his most important foreign policy address since taking office. His "quarantine" speech refuted strict neutrality and appealed for "a concerted effort” to ostracize aggressive dictatorships_Japan, Italy, and Germany. 
The president understood the last as the most dangerous and a threat to US interests. The speech met a mixed reception in the US, where isolationism remained influential. Nevertheless, the address revealed the growing appeal of anti-fascism among the press, public, and artists. In the late thirties the fascist menace alarmed prize-winning American authors and poets-Lewis Mumford, Van Wyck Brooks, Carl Sandburg, and Archibald MacLeish. MacLeish, a non-communist anti-fascist who argued for early intervention in Europe, stated, "A free people cannot fight fascism unless it believes with even greater conviction that freedom is good ... and that slavery is evil" (Alpers 2003, 16; Jonas 2011, 439; MacLeish cited in Whiting 1989, 108).

Some Republicans, such as the widely read columnist Dorothy Thompson, also embraced anti-fascism in the 1930s. Thompson, who was expelled from Germany in 1934 and whose image graced the cover of Time in June 1939, was likely second only to First Lady Eleanor Roosevelt as the most influential American woman. She represented the views of the overwhelming majority of well-known American reporters in Europe-Edward Murrow, William Shirer, John Gunter, Vincent Sheean-who were anti-Nazi and antiappeasement (Cull 1999, 221). Thompson alerted conservatives that fascism was a "TOTAL [sic] revolution ... pushed forward not by classes but by whole nations" which could be lethal to democracy (Bosch 2012, 230; Sanders 1973, 218, 225, 253; Washington Post, March 31, $1939,17)$. Thompson's conservative anti-fascism allowed her to be "among the first to grasp and publicize the Nazis' murderous intentions toward the Jews of Europe" (Moore 2010, 57). As early as 1934 she had reported that the Nazis wanted merely "submission" from other groups but aimed "to eliminate" the Jews (Thompson 1934, 12 [italics in original]). Yet she usually de-emphasized National Socialism's special hatred of Jews to focus on its intolerance of many groups. Her efforts effectively broadened the US antifascist coalition to include all religious and ethnic groups and markedly appealed to the white, Protestant majority, of which she was a member.

The Nazis' quick consolidation of power in 1933-1934 increased American misgivings concerning Italian Fascism, which now appeared as a dangerous ideological precursor and partner of the National Socialists. The Italian invasion of Ethiopia in 1935 confirmed these qualms. Despite 
the passage of the Neutrality Acts in the same year, Congress and the administration grew increasingly indignant about Italian actions in Abyssinia. Roosevelt began to doubt his previous judgment that the Duce was an "admirable Italian gentleman", even if he continued to regard the Italian dictator as considerably less dangerous than Hitler. The president addressed Congress in January 1936 and condemned Fascism's "twin spirits of autocracy and aggression". Mussolini's imperialism did not disturb him as much as his unprovoked violence did. To discourage pro-Fascist Italian American and anti-Fascist African American volunteers, the administration warned US nationals who volunteered to fight in the Ethiopian conflict that they would be subject to fines, imprisonment, and, in the case of naturalized citizens, possibly forfeiture of their citizenship. By imposing several sanctions against the Italian regime, Roosevelt overruled his own ambassador to Italy, ignored pro-Fascist sentiment among Italian Americans, and took the risk of provoking nationalist reaction in Italy itself. Italian aggression in Africa also alienated some businessmen who had admired the Fascist experiment. To show his disapproval, Henry Ford cancelled an order prepaid by the Italian government for eight hundred motor cars. The UK's proposed recognition of Italian conquests in Ethiopia provoked a direct protest by Roosevelt to Prime Minister Neville Chamberlain and in February 1938 the resignation of the more Atlanticist Anthony Eden as foreign minister. The US government remained nearly alone in refusing recognition of Italy's African victory (Tierney 2007, 29; Diggins 1972, 291, 303-312, 352).

\section{Anti-Semitism}

Not surprisingly, American Jews were among the most active anti-Nazis, and many were cognizant of the centrality of anti-Semitism in German fascism. Immediately after the regime took power, Bernard S. Deutsch, the president of the American Jewish Congress, recognized the Nazis' "avowed program of exterminating the Jews". So did Rabbi Stephen S. Wise, who called Hitlerism "a new phenomenon in world history" which refused to tolerate human differences. In 1934 James Wise, the editor of the Jewish journal Opinion, offered a sophisticated verdict: “It is impossible to label 
it [Nazism] as a revolutionary or reactionary movement and thus to pigeon-hole its aims and acts... To dismiss Nazism as a German variant of Fascism and nothing more is to confuse, not clarify the issue. Differences in degree, if they are great enough, become differences in kind". Although supposedly progressive American opinion was not opposed to the sterilization of "defectives", it rejected the singling out of Jews. As in Britain, Jews provided many of the shock troops for anti-Nazi demonstrations in major cities-New York, Newark, Chicago, and Los Angeles. Municipal authorities often tolerated their attacks on Nazi Bundists (Wise 1934a, 44; Wise 1934b, 207; Grill 2003, 23; Bernstein 2013, 127).

Anti-fascists normally treated Jews as a religious group, not as an ethnicity or race. In fact, antiracism was a relatively minor component of transatlantic anti-fascism. Leftists focused on Nazi ties to big business and established German elites, not on its bigotry. Both Marxists and anti-Marxists breezily dismissed Nazi discrimination as demagoguery. The dominant argument was that persecution of Jews was not qualitatively distinct from that of other minority groups. This was especially true of Communist anti-fascism, but it also characterized elements of conservative anti-fascism. Both usually failed to recognize the racial principle upon which Jews' exclusion and ultimately genocide was based. In fact, many interpreted Nazi anti-Semitism as simply a cover for extortion of Jews. In the US, as well as in the UK and France, traditional patriotismnot antiracism - motivated the anti-fascist struggle. Indeed, anti-fascism was compatible with nonlethal varieties of anti-Semitism and violent antiblack prejudice.

Following the November 1938 Reichspogrom, Roosevelt — who returned Hitler's personal antipathy — recalled the American ambassador. The US president, who throughout the 193 os considered Hitler a "madman" and the Germans bullies, was the only world leader (not excluding the pope) to condemn the November pogrom. His public disapproval demonstrated the uniqueness - whatever its considerable limitations - of the American concern for persecuted German Jews. American Jews were joined in their protests of anti-Semitism by mainstream Republicans, such as former President Herbert Hoover, and conservative veterans' organizations, such as the American Legion, which firmly opposed Nazism throughout the 
1930s. The US armed forces also rejected German anti-Semitism in their publications. In January 1938, an opinion poll revealed that 94 percent of Americans disapproved of Nazism's treatment of Jews. In December 1938, 61 percent of Americans were prepared to participate in a boycott of German-made goods (Ascher 2012, 194; Moore 2010, 76; Johns 1946, 281, 292)

American Jews composed at least one-third of the Abraham Lincoln Brigade, which fought for the Spanish Republic. Its defeat was a victory for fascism and bolstered the prestige and confidence of Germany and Italy. Yet paradoxically, the fascist triumph provided positive opportunities for counterrevolutionary anti-fascism. Conservative anti-fascists could henceforth focus on the central German threat, not the Spanish diversion. Antifascists no longer needed to disperse their energies among a number of fronts-Ethiopia from 1935 to 1936, Austria in 1938, and Spain from 1936 to early 1939 - and could concentrate their political and cultural energies on Nazism. Most importantly, the end of the Spanish conflict freed antifascism from its association with revolution, communism, and anarchy. The war's closure permitted anti-fascists to construct a broader alliance with Catholics and conservatives in the face of persistent German and Italian expansion against nonrevolutionary states. The Spanish conflict's termination mended the rift between Britain and France over Italian aggression in the Iberian Peninsula, where the French were much more hostile to the empire building of their Mediterranean rival. The end of the Spanish war facilitated a coalition which would eventually defeat the Axis in World War II. The outcome of the Spanish conflict was not only-as many historians have argued-an example of appeasement of fascism by the Western democracies but a critical and unexpected step towards the formation of an altered anti-fascist unity. In fact, in 1937 Hitler expressed the desire for the Spanish war to continue as long as possible - even to the end of 1940 -in order to divide his potential enemies. In other words, Franco may have won the war too quickly from the Nazi perspective, rather than too slowly as many of his critics and some supporters have argued. Perhaps the revolutionary Republic had to be defeated before a more inclusive anti-fascist coalition could occur (Thomas 1996, 216, 234; Steiner, 2011, 242).

Italy's adoption in 1939 of Germany's anti-Semitic policies - a telling example of Fascist deference to Nazi supremacy—angered many Ameri- 
can publications. The conservative and pro-Franco Catholic World condemned the Duce's “Aryan madness". Generoso Pope, an Italian American millionaire and press magnate who had steadfastly supported Mussolini, broke with the regime over its recently adopted anti-Semitism. Aping the Nazi line, official Fascist propaganda reacted by conducting a venomous campaign against prominent American Jews and "Hebraized" Gentiles who were allegedly responsible for an anti-fascist foreign policy. Likewise, the unfavorable American reaction to Kristallnacht confirmed the Nazi belief-shared by others on the US and European extreme right-that Roosevelt was "the mouthpiece of Judah and the instrument of the Comintern" (Catholic World cited in Diggins 1972, 319; German propaganda cited in MacDonald 1989, 306). In other words, Jews were purportedly behind both revolutionary and counterrevolutionary anti-fascism.

\section{US policies toward Nazi Germany}

In the second half of the 1930 soosevelt opposed German rearmament and attempted to bolster the position of the Western democracies against potential foes, and especially against Nazi Germany, which was considered the most dangerous economic and military threat. Always skeptical of appeasement as practiced by Chamberlain, by the end of 1938 the president became convinced of its failure. Although Roosevelt initially supported and even attempted to share in the credit for the Munich Agreement of September 1938, he quickly had second thoughts, particularly after Kristallnacht in November (Harrison 1990, 117-119, 124-127; Trubowitz 2011, 65-71).

The president believed Hitler would repeat his previous violations of agreements, and he made clear to the British that if they fought vigorously he would back them if war erupted. US public opinion supported the president. Seventy-seven percent felt that German annexation of the Sudetenland was unjustified. Backed by an overwhelmingly pro-Allied public, Roosevelt resolved to contain the Axis, principally the Reich, by methods short of war and without completely alienating isolationist opinion. The president's antiappeasement positions made his relationship with isolationists - that is, those who wanted to avoid American involvement-in- 
creasingly fraught. Nevertheless, he embarked upon a policy of incipient anti-fascism, which included substantial American rearmament and dividing Italy from Germany. As in the other Western democracies, Mussolini's popularity regained a bit of its lost luster since some still considered him a potential counterweight against German expansionism (Harrison 1990, 131; Johnstone 2014, 36; Tierney 2007, 70; Casey 2001, 9; Brendon 2000, 515; MacDonald 1989, 297-298).

The perception, subsequently confirmed by many scholars, that the Nazis had long-term plans to attack the Western hemisphere from bases in the Atlantic and Northwest Africa deeply worried the Roosevelt administration. In addition, Washington was concerned that certain Latin American nations might cooperate with the Franco and Hitler regimes. The administration became anxious about fascist expansion in Latin America in the mid-1930s and regarded Franco's Spain as a possible spearhead for fascist subversion. By 1936 Germany was the second-biggest exporter to Latin America, and the alleged pro-Nazi tendencies of the one million Germans living on that continent concerned both internationalists and isolationists (Tierney 2007, 28; Winkler 2015, 634). Secretary of State Cordell Hull held that German minorities, as they had done in Czechoslovakia, could destabilize Latin American states from within. In the mid-1930s, Hull began to consider fascism a greater danger than Communism. In early 1939, the president attempted to deter Germany by providing political and possibly economic backing for Great Britain, France, and Poland. He leaked his confidential comments to the Senate Armed Forces Committee that in a crisis the US could not avoid supporting France and Britain (McKercher 1999, 274). The administration also encouraged an alliance of the Western democracies and the Soviet Union.

In early 1939, a Gallup poll showed solid support among the US public to help Britain and France if the Reich attacked them. Sixty-two percent of Americans believed that if Germany defeated the Allies, it would then assault their own nation. As in the other major democracies, the Prague coup of March 15, 1939, allowed Roosevelt to take stronger measures against what was increasingly perceived by his administration as the Nazi menace. Immediately after the German invasion of Prague, the US ambassador to France, William Bullitt, who was anti-Soviet and anti- 
Versailles, nonetheless argued that Washington should aid both Britain and France to check Germany. In late March 1939, duties were imposed on German goods, and British and American naval deployments in Europe and Asia were coordinated to discourage both German and Japanese aggression. The latter's belligerence aroused particular opposition from American Protestant missionaries in China, who formed an effective lobbying group, the American Committee for Non-Participation in Japanese Aggression, whose honorary chairman was Republican politician Henry Stimson. The ACNPJA was pleased when on July 26, 1939, the administration ended the 1911 Treaty of Commerce and Navigation with Japan and consequently reduced trade with that nation. However, after the European war erupted, the Roosevelt administration and public opinion continued to regard Germany (and specifically Hitler) as a greater threat than Japan (Schmitz 1990, 97; McKercher 1999, 272; Johnstone 2014, 19, 51, 66-67; Mayers 2013, 131-133).

In June 1939 the first visit to the US by a reigning British monarch bolstered the popularity of the UK in US public opinion and promoted the transatlantic cooperation desired by both governments. In July 1939, Roosevelt warned the Soviet ambassador that an agreement between Germany and the USSR would not prevent an eventual German attack on the Soviet Union. The Soviets disregarded that advice and signed a pact with Germany that encouraged the invasion in the fall of 1939 of the conservative republics of Poland and Finland. Both nations received the sympathy and sometimes the material assistance of the Western democracies, including the United States, which, however, refused to envisage war over the issue. Ultimately, the democracies avoided imposing significant sanctions on the USSR; they feared such measures might further solidify the Soviet-German alliance (MacDonald 1989, 312-322; Steiner 2011, 814; Johnstone 2014, 62; Mayers 2013, 217-218).

Despite the president's desires to help the democracies in the months following the German invasion of Prague, in April and July 1939 a combination of isolationists and anti-New Dealers blocked revision of the Neutrality Act and maintained the US arms embargo on belligerents. Isolationists reasoned that the Western hemisphere was secure from attack by any combination of potential enemies. Their vision of "imperial isola- 
tionism" was similar to that of Viscount Halifax in Britain or Pierre-Étienne Flandin in France, who argued before the war that retreat into empire would guarantee national security and preserve peace with a greater Germany (McKercher 1999, 7). Like British and French appeasers, American isolationists - individuals such as Charles Lindbergh and groups like the America First Committee-regarded their internal enemies as more dangerous than their external adversaries. European appeasers considered Communists, "warmongers", and Jews as foes. By contrast, American anti-interventionists focused on the Roosevelt administration, the British, and Communists, usually targeting Jews only privately. Like the left, isolationists charged that their foes were "fascist" or "Hitlerian". Nonetheless, even after the European war began, isolationists continued to argue that a reasonable settlement could be negotiated with Hitler. Isolationistssuch as America First leader General Robert Wood and the anti-Semitic Henry Ford - evoked a guilt similar to the Europeans' Versailles contrition that blamed the aggressed for the aggression, and they would finance pamphlets that posited that the Roosevelt administration had manipulated the Japanese to attack Pearl Harbor (Cole 1983, 537-548). Versailles' war guilt clause did more damage to anti-fascism in the US, France, Britain, and elsewhere than it did to German nationalism. Blaming the Great War solely and simplistically on Germans allowed for the reversal of war culpability and helped to legitimize the Nazis. Versailles culpability assumed Allied injustice and German victimization. Versailles remorse was necessarily Gallo-, Anglo-, and American-centric and thus obscured the dynamics of Nazi militarism. Versailles culpability induced large sectors of the left and the right to excuse German aggression. Both left and right blamed Versailles and the French for the rise of Nazism. Anti-Versailles and Francophobic sentiments were common in the Dominions, and many Americans also considered the French as the chief threat to peace in the early 1930s. Guilty conscience made the so-called status quo powers nearly as revisionist as Italy and Germany (Gannon 1971, 4-6, 12; Ovendale 1989, 189).

Polls showed that Americans were determined to remain formally neutral in 1939. Though eroding during the late 1930 s and early 1940s, isolationist sentiment remained potent in Congress and in public opinion, 
especially in the Midwest. Isolationist arguments rested on pacifism and anti-communism and alleged that Hitler's Germany was not dangerous to the US, and therefore that aiding the Allies was unnecessary. Congressman Hamilton Fish, a New York Republican, and others contended that war against Germany would lead both to the end of American democracy and to Communist domination throughout the world. Colonel Robert R. McCormick, owner of the Chicago Tribune, endorsed these views, which led him to overlook Nazi anti-Semitism. He and other newspapermen, including the widely published interventionist Walter Lippmann, shared the common trope which attributed German Judeophobia to the victimization of Germany by the Treaty of Versailles (Lipstadt 1986, 28, 42, 46).

Isolationists in the Roosevelt administration-Sumner Welles, undersecretary of state, and notably Joseph Kennedy, ambassador to the UKbelieved that the injustices of Versailles created Nazi radicalism, and both men were antagonistic to the British and zealously anti-Soviet. In the summer of 1938 , in conversations with the German ambassador to the UK, Kennedy had attributed to Jews the existing anti-German sentiment in the US. One month before Kristallnacht, he assured a Reich diplomat that Americans sympathized with German anti-Semitism. Kennedy shared his friend Lindbergh's defeatism and resigned in November 1940 after warning Jews in Hollywood, some of whom-Fritz Lang, Oscar Hammerstein, Frederic March-were prominent in the Anti-Nazi League, not to be actively anti-fascist, whereas Welles abandoned his previous analysis and converted to a policy of opposition to fascism (Vieth 1990, 58; Mayers 2013, 63; McKercher 1999, 293). The new ambassador to the UK, John Winant, a former Republican who had formed close ties to Britain's Labour Party, was a passionate interventionist.

Only in November 1939, nearly two months after the war erupted in Europe, could the Roosevelt administration convince Congress, where rural isolationist sentiment was disproportionately strong, to modify the neutrality laws to accomplish two complementary goals: the expansion of American business activity and the provisioning of the European democracies. The House voted 243-172 to approve the revision of the Neutrality Act. The support of 110 of 118 Southern congressmen was essential for its passage. Dixie's dependable and overwhelming approval reflected 
its Wilsonian internationalism and enthusiastic Anglophilia. A militaryfriendly internationalism overcame pacifism and isolationism (Lynch 1999, 160-170). US public opinion overwhelmingly backed the legislation (Johnstone 2014, 55). In October 1939, 59 percent of Americans supported aid to Britain even at the risk of war. The government permitted cash arms sales to France and the UK. In November the "cash-and-carry bill", whose passage had previously failed, permitted these nations and other potential allies to buy as many weapons as their resources permitted. American businessmen, who hated to see their machines idle, welcomed fat contracts from any government. The first cash-and-carry orders originated from the UK and France, whose preparation and commitment to fighting the Germans allowed the American aviation and armaments industry valuable time and resources to prepare for even bigger deals from its own government. Furthermore, Roosevelt ordered that the treasury purchase materials and supplies needed by the Germans and Russians (McKercher 1999, 284). While the Soviets were supplying Germany with raw materials and foodstuffs, the US sold arms to defeat the Axis and prohibited sales of strategic materials to potential enemies (Johnstone 2014, 88). Authorization to sell arms to the anti-fascist Allies contrasted significantly with the US refusal to vend weapons to the Spanish Republic during its civil war. By the end of the year, 68 percent of Americans thought that facilitating the defeat of Hitler was worth the risks (Fry 2002, 189, 203; Chadwin 1970, 197). ${ }^{1}$

Despite fascist accusations, philo-Semitism in the US proved less consequential than Anglophilism. The East Coast possessed an entrenched current of the latter which surfaced vociferously after the UK entered the war. The Century Group, composed of several dozen members of the eastern establishment-businessmen, media executives, and religious leaders-formed in 1940 in New York to aid Britain. All its members were white males, and twenty-two out of twenty-eight were Protestants largely of an Anglo-Saxon background. These men were a nearly equal mixture of influential Democrats and Republicans, including magazine (Time, Life, and Fortune) and newsreel (March of Time) magnate Henry Luce. A ma-

${ }^{1}$ For similar figures, see Johnstone (2014, 74). Dunn (2013, 35), downplays pro-Allied public opinion. DICTATORSHIPS \& DEMOCRACIES 7 (2019) · E-ISSN: $2564-8829$. PUNCTUM, UNIVERSITAT OBERTA DE CATALUNYA \& FUNDACIÓ CARLES PI I SUNYER 
jority were conservative on domestic issues but were willing to risk war with Germany and during this period - when the Hitler-Stalin pact was in effect - with the Soviet Union as well. They viewed Nazism as similar to Communism - a revolutionary phenomenon which endangered private property and traditional religion. This elite feared that a German victory over Britain - whose likelihood increased after the fall of France-would entail Nazi control of the British fleet and the Atlantic and thus put the US in direct danger.

Roosevelt's hopes to isolate Germany were destroyed by the fall of France in June 1940, which brought Italy officially into the war on the German side and stimulated Japanese expansionism in Asia. The German conquest of the nonthreatening nations of Belgium, Netherlands, Denmark, and Norway alienated both official and public opinion of their fellow American neutral. The anti-Communist Bullitt reasoned that Germany's defeat of France would jeopardize US security (Mayers 2013, 135). The fall of France and the Netherlands in 1940 increased concern that those nations' imperial possessions could be used as bases for German naval attack or political subversion in the Western hemisphere. To counter this threat, in 1940 Roosevelt named the wealthy young Republican Nelson Rockefeller as coordinator of inter-American affairs.

The Italian attack on nearly defeated France in June 1940 estranged many even in the largely philo-Fascist Italian American community. In New York alone 122 Italian groups condemned the invasion of France and agreed with Roosevelt's characterization of Mussolini as a "backstabber" who knifed a neighbor from behind. Mussolini's image in the US became that of a "jackal". Americans and their government might have (barely) tolerated the Duce - as they did Franco-if he had not entirely linked his fate with that of Hitler even after Roosevelt had attempted to persuade him at the end of May 1940 to keep Italy out of the war. When Italy declared war on the US three days after Pearl Harbor, Italian Americans denounced the Duce and demonstrated solid loyalty to their adopted nation. The power of American assimilation was also evident in the failure of the Nazified German American Bund to attract a significant membership of German Americans, who comprised perhaps a fifth of the population and the massive majority of whom showed a firm commitment to 
the US war effort. They rejected the Bund's appeal, which was based on both Aryan brotherhood and resentment of anti-German hysteria in the US during World War I (Diggins 1972, 350, 359; Keating 1996, 66; Olson 2013, 124; Bernstein 2013, 18, 26-27; Bell 1970, 587).

The collapse of conservative republics and constitutional monarchies in Western Europe sparked further American efforts to prepare for war. In effect, the US would replace France as the UK's major counterrevolutionary anti-fascist ally. The elites of both countries supported this arrangement to counter both real and potential enemies in Europe and Asia, but the UK would pay a higher price for American support than it would have if France had remained in the war. Greater American power and wealth would eventually leave Britain in a weaker position at home and abroad (McKercher 1999, 302-309). Britain's coalition government, which included trade unionists, inspired theirAmerican counterpart - many of whose members had been isolationist - to become actively anti-fascist. In July 1940 Roosevelt appointed Henry Stimson - a strongly interventionist Republican, a member of the Committee to Defend America by Aiding the Allies (CDAAA), and President Hoover's former secretary of state-as secretary of war to replace an isolationist member of his cabinet. At the same time and for the same reasons, the president named Frank Knox, also a CDAAA member and a former Republican vice presidential candidate in 1936, as secretary of the navy. Knox was the publisher of the Daily News, the only interventionist Chicago newspaper and a forceful Republican proponent of US military preparedness and aid to the Allies. An Anglophile, Knox criticized his own naval officers for their "defeatism", which was widespread among isolationists. Like Stimson, he had lobbied and would continue to lobby influential anti-New Dealers in his own party to support intervention against Germany. Until Pearl Harbor, in Roosevelt's cabinet both present and former Republicans-Knox and Stimson, along with Secretary of the Interior Harold Ickes and Secretary of Agriculture Henry Wallace-were more aggressively interventionist than Secretary of State Hull or even the president himself (Reynolds 1990, 334; Offner 1975, 177; Olson 2010, 68; Lichtenstein 1982, 42; Cole 1983, 368, 441, 482).

After Britain rescued its soldiers at Dunkirk in June 1940, Roosevelt overruled his military advisors - who objected that the US had no weapDICTATORSHIPS \& DEMOCRACIES 7 (2019) · E-ISSN: 2564-8829 - PUNCTUM, UNIVERSITAT OBERTA DE CATALUNYA \& FUNDACIÓ CARLES PI I SUNYER 
ons to spare for a UK uncertain to survive-and ordered the shipment of all possible aid to the British (Herman 2012, 87; O'Neill 1993, 18; Dunn 2013, 40). The action anticipated his own order and that of Churchillwhich were again disputed by their military chiefs-to send as much assistance as possible to the Soviet Union after the German invasion of June 1941. Neither leader underestimated the USSR as many of their advisors and opponents did. On June 15, 1940, as the British government was preparing to demand that the French fleet be sent to British ports, Churchill warned Roosevelt that if the British fleet "were joined to the fleets of Japan, France, and Italy and the great resources of German industry, overwhelming sea power would be in Hitler's hands". If Britain fell, a Quisling government would undoubtedly try to obtain the best terms by using the Royal Navy as its bargaining chip, just as the Vichy regime had done with its fleet. Aware of the danger and distressed about a possible Axis presence in Latin America, the president decided to do what he could to assist the British war effort (McKercher 1999, 295).

American interventionists such as William Allen White and General John Pershing of the CDAAA began to lobby to convince public opinion and Congress to aid the Allies. Pershing was generally recognized as the country's most distinguished soldier, and CDAAA leader White was a Republican who provided an additional degree of bipartisan support to the administration. He was also from the Midwest, a region that was predominantly isolationist. Born in May 1940, the CDAAA became the most prominent interventionist organization and, with the support of the administration, pushed effectively to approve trading American destroyers to Britain in return for American bases on British territory throughout the Atlantic, which would be one of the most important territorial acquisitions of the US since the Louisiana Purchase (1803). Interventionists insisted that the UK issue a public pledge to never surrender its fleet to the Nazis. In the year before Pearl Harbor, interventionists were particularly successful in gaining the support of organized labor. They counterattacked those who claimed that opposition to Hitler was a Jewish conspiracy by accusing their adversaries of mouthing Nazi propaganda. Interventionists built a multiracial and cross class anti-fascist coalition that included African American leaders such as Reverend Adam Clayton Powell Sr. and 
union president A. Philip Randolph (Lincoln 1970, 71, 84, 269; Gates 1981, 437; Dunn 2013, 182).

The Tripartite Pact of September 1940 announced the development a defensive German-Italian-Japanese alliance that sought to intimidate the US and discourage it from assisting Britain. The pact estranged a broad base of opinion in the US and further undermined a declining isolationism. Although the administration still sought to avoid outright involvement in the war, it advanced plans to supply the UK on credit and deployed American naval power to discourage Axis attacks (MacDonald 1989, 323). Britain quickly exhausted its cash reserves, and in December 1940 the Republican-Democratic consensus in Congress moved toward approval of British purchase of needed materials on credit.

Effective foreign aid often functions as a system of matching grants, common in American philanthropy, whereby potentially larger donors match the sums of initial donors who demonstrate dedication and sacrifice to the cause. An excellent example of this principle was the British military performance, which fortified American interventionists. The combative anti-fascism displayed by Churchill, the RAF, and the British people during the Battle of Britain in the summer and autumn of 1940 won the admiration of most Americans. If the fall of France was the greatest blow to conservative anti-fascism, Britain's survival was its greatest triumph. Although less dramatic than the unexpected French collapse, British endurance proved even more consequential by creating a war of attrition which transformed all the great powers into belligerents. By September 1940 the American government considered that the production of war material for use by Great Britain was "essential for the national defense of the United States" (Herman 2012, 100). At that time, the president announced a destroyer deal with Britain which bolstered American strength in the Atlantic. The US traded fifty to sixty World War I destroyers to the UK in exchange for the establishment of American military bases on British territory (Newfoundland, Bermuda, Bahamas, Jamaica, and so forth) in the Western hemisphere. In addition, the UK pledged that it would never surrender its fleet.

Many isolationists opposed the deal, despite its obvious value for transatlantic defense, but anti-fascist Democrats and Republicans-includ- 
ing the Republican presidential candidate in 1940, Wendell Willkie-endorsed it. Like Roosevelt, Willkie believed that the Royal Navy, the most formidable of the globe, was essential for American security (Cole 1983, 98). The Roosevelt administration — backed by the fervently anti-Nazi and pro-British Willkie, influential labor leaders, and sectors of public opinion stunned by the fall of France-launched a massive expansion of arms production and of the armed forces. American Anglophiles campaigned to institute a draft. Their efforts garnered bipartisan support and culminated in the narrow approval of the first peacetime conscription-again managed through Congress by Southerners-in September 1940. The peacetime draft gained a legitimacy that it never previously possessed in US history. Hitler's conquests helped the anti-fascist Roosevelt win reelection to an unprecedented third term in November. In a radio address on December 29, he insisted that the Axis powers were "an unholy alliance" seeking "to dominate and enslave the human race". In this fireside chat, he asserted "a nation can have peace with the Nazis only at the price of total surrender". He proposed that the US become "the great arsenal of democracy" by supplying Britain and its allies (Offner 1975, 193; Sparrow 2011, 205; Cole 1983, 412).

\section{US Christian Anti-fascism}

A particular concern of the interventionists was to persuade American Catholics - many of whom were of Irish ancestry and frequently hostile to Britain-to moderate their support for appeasement. The relatively few Catholic anti-fascists in the Century Group emphasized Hitler's supposed intention to "exterminate Christianity". Christians in the most important interventionist groups viewed the Führer as a representative of the forces of evil and argued that the survival of Christian civilization depended upon the endurance of the UK. In 1939 the prominent Protestant theologian Reinhold Niebuhr broke with his previous pacifism - which had been disseminated by the liberal Protestant review Christian Centuryand argued for American intervention against Nazi Germany (Chadwin 1970, 147; Crouter 2010, 6; Fox 1985, 186-191). 
Niebuhr tried to alert the public that Chamberlain's appeasement policies were hardly "realist" and spelled doom for Europe: "The Munich [Agreement] represented a tremendous shift in the balance of power in Europe. . . It reduced France to impotence, ... it opened the gates to a German expansion in the whole of Europe, ... it isolated Russia and changed the whole course of history". Niebuhr linked his condemnation of Munich to the misapprehension of the Treaty of Versailles: "The really tragic end of a liberal culture is to be found in the peace of Munich. What was best in that culture was outraged by the peace of Versailles and what was shallowest in it came to the conclusion that the horrors of a peace of conquest could be expiated by a peace of capitulation". After the fall of France, Niebuhr criticized the French as "sick" for their quick surrender to the Germans and embarked upon an antineutralist campaign to convince Americans to support the UK. In early 1941 Niebuhr and other prominent Protestant clergymen-some of whom were members of the Century Group-established a new "journal of Christian opinion", Christianity and Crisis, to awaken the faithful to the dangers of isolationism and the necessity of intervention. It identified an Allied victory with "the rescue of Christendom". Niebuhr and his colleagues brought their message to many audiences, including the conservative, if not racist, Daughters of the American Revolution. They maintained that pacifists and revolutionary socialists were "utopians" who did not understand the nature of the Nazi foe. Unlike many other so-called "realists" in the Atlantic world, Niebuhr linked the domestic developments of the Reich-notably its persecution of Jews-with its international aggression. Loving one's enemies did not mean that one could not fight them, but rather that they were recognized as fellow human beings even in war (Niebuhr cited in Inboden 2014, 71-72; Edwards 2012, 83).

He and his group of Christian realists viewed both fascism and communism as pagan utopias that manufactured false religions which idolized the state. He proposed that Christians imitate the ancient prophets and engage in worldly activities to counter these "totalitarian" states. The increasing popularity in the 1930 of the concept of totalitarianism among the right, the center (including American Lutherans), and also the antiStalinist left undermined sympathies for the Third Reich, even before the 
Nazi-Soviet nonaggression treaty of 1939 reinforced the identification of both regimes. Niebuhr's assertion that Nazism was a return to "slavery with technical efficiency" provided an insightful twist on the slavery interpretation common to many anti-fascists by pointing to fascism's dangerous modernity. The interpretation of fascism as a regression to slavery had special resonance in the US, which, of course, had fought its greatest war over the issue. The British Conservative leader Baldwin expressed himself in similar terms, evoking in March 1934 the existence of "slavery" from the German Rhine to the Russian Pacific. After the German occupation of Czechoslovakia in March 1939, French Socialist leader Léon Blum likened Nazi domination to "slavery", as did descendants of Africans in the French Caribbean (Gombin 1970, 237; Jennings 2000, 64). Slavery was the metaphor which linked the fight against Nazism to the abolitionist campaigns of Enlightenment thinkers and evangelical Christians, both of whom were especially influential in the developed Atlantic world.

Niebuhr might have added that Nazism and Communism also propagated a work ethic run amok. Indeed, fascism and Communism broke with previous slave systems. Unlike their aristocratic predecessors, whodisdained labor and believed it worthy only of slaves, fascists - much like their communist enemy-glorified workers and their work. The mass enslavement which was popularized by Aryan elites in a dynamically hardworking civilization alarmed the descendants of abolitionists, who had fought bondage in more traditional societies. The return of slavery in Nazi Germany (and the Soviet Union) ephemerally rattled faith in the superiority of free over slave labor. In many ways, devotion to labor combined with martial spirit is what made fascism a powerful and modern ideology that was capable of conquering and holding off other great powers for six years. Free-market-oriented Americans feared that they could not compete in a world where fascist powers created autarkies which employed forced labor or what was labeled "military socialism" (Johnstone 2014, 9, $85,123)$. Capitalists and liberals were suspicious of this "socialism", and German militarism aroused fears about new Nazi warlords who would engage in massive slave raiding. The slogan of US interventionists in the late thirties was “You can't do business with Hitler". What can be called anti-fascist abolitionism among the Western Allies united capitalists and 
workers into an imagined community of labor, as abolitionism had in the nineteenth century. Protestants had been leading abolitionists, a movement largely of their creation in the Anglo-American world, but by September 1939 Archbishop Francis Spellman of New York, often considered the leader of American Catholics, joined the anti-fascist ranks by arguing against a "peace of slavery". Before Cardinal Mundelein of Chicago died in October 1939, he had instructed surrogates to broadcast his appeal to amend the neutrality laws (Niebuhr quoted in Fox 1985, 195; Spellman cited in Zietsma 2007, 563; Wapshott 2015, 147).

As in Britain and France, in America the interpretation of Nazism as a pagan revolt and a regression to medieval savagery was common. As early as 1934, Roosevelt warned that dictators were preparing a new dark age. At the same time, John Haynes Holmes, a Unitarian minister and a pacifist during both world wars, declared that "Hitlerism is a reversion to barbarism”. "The Nazis", he claimed, "tested by every standard of modern civilization, are savages" who were replacing God and Christ with Wotan and Siegfried. Like their British counterparts, American Protestants united against Hitler's campaign to create a "German Christianity" which placed churches under state domination. Prominent Protestant and Catholic publications avoided representations of European dictators as humorous or amusing since, they argued, comical portraits risked underestimating the fascist danger to America. The lampooning of the hysterical style of the Führer and the widespread recognition of his intellectual limitations often prevented English-speaking audiences from taking him seriously. Chaplin's The Great Dictator (1940) — one of the most powerful representations of this tradition which would continue in Hollywood films and cartoons produced during the war-may have contributed to American complacency (Brendon 2000, 513; Holmes 1934, 128-132; Alpers 2003, 86).

Christian anti-fascism captivated political leaders in the US as it had elsewhere. Like Churchill, Roosevelt often tied his anti-fascism to traditional religion. As assistant secretary of the navy during World War I, the future president had already juxtaposed German paganism with Christianity. As president, he interpreted the fall of France as accelerating the confrontation between democracy and dictatorship and between religion and godlessness. 


\section{US Regional Anti-fascism}

Numerous analysts have regarded fascism as a reactionary movement and a regression to a more backward era. Given these views, the antifascism of the semifeudal US South was remarkable. The South rejected Italian Fascism because nativists, right-wing Protestants, and Klansmen considered Mussolini as an ally of the pope and an alien anti-Christ. The Ku Klux Klan sent flowers to a New Jersey policeman who had been suspended for removing a Fascist flag from the lead car during a parade of Italian American Blackshirts. Comparisons which emphasized affinities of the Klan with the Italian movement upset Klansmen, who rhetorically rejected all "isms", including fascism. Their fraternal relations with the German American Bund deteriorated during World War II when the Klan's Imperial Wizard wanted to join the Catholic Knights of Columbus and the Jewish B'nai B'rith in patriotic cooperation (Diggins 1972, 19, 207; MacLean 1995, 183; Chalmers 1965, 274, 323, 234). The Klan's anti-fascism is indeed ironic since it has been viewed as "a remarkable preview of the way fascist movements were to function in interwar Europe" (Cf. Paxton 2004, 49, and MacLean 1995, 180-181). The Klan's uniforms, violence, and alliances with more conventional conservatives did resemble European fascist movements, but it was too backward looking to be classified with Fascism and Nazism. Its Protestant exclusiveness circumscribed its national influence, as did its hatred of the omnipotent national state which nearly all European fascisms preferred. Its preference for local control and states' rights harkened back to the Confederacy. The Klan's neotraditionalism sought a return to the racist traditions of the antebellum South and segregationist North, where African Americans "knew their place" and provided cheap and compliant labor. It did not envisage building new genocidal empires.

The Southern press denounced Nazi anti-Semitism. Bible Belters and secular Southerners objected to the replacement of Old Testament stories with an Aryanized Jesus and Nordic sagas. African American newspapers reported Hitler's reference in Mein Kampf to blacks as "half-apes" and called the Führer "the master Ku Kluxer of Germany". A number of African American journalists perspicaciously reminded their readers that Hitler 
would abolish all constitutional rights and bring back slavery. Although the black media and intellectuals—such as W. E. B. Du Bois-condemned anti-Semitism, they often mimicked, as did their white counterparts, the prejudices of the Germans by assuming the Jews' supposed devotion to money, their reluctance to serve in the army, and their domination of certain professions. Black journalists also engaged in a competition for victimhood in which black suffering in the US equaled or surpassed any comparable Jewish pain in Germany. Nevertheless, by the end of the 1930s, the Southern secular and religious press clearly condemned Nazism. African American newspapers would rally around the war effort (Grill 2003, 20-32; Blower, 2014, 335; Chadwin 1970, 186; Plummer 1996, 67).

During the war, Nazism became so unpopular that some government officials suggested that emphasizing Nazi views on Jews would undermine anti-Semitism in the US. A Southern conservative intellectual, Richard M. Weaver, argued that the South had retained an antidemocratic conservatism that encouraged its rejection of revolutionary Nazi doctrines. In other words, Southern segregationists were happy to join the anti-fascist coalition. In fact, the South was the region where polls consistently showed the highest support for anti-Nazi interventionism. Southern martial culture yearned for a fight with a rival militarism. The enlistment of the entire Lepanto, Arkansas, football team in the navy after Pearl Harbor showed deep popular support for anti-fascism. White Southerners and their supporters were enthusiastic participants in a campaign which combatted a form of racism even more virulent than their own brand. The racist anti-fascists of the American South were aggressively anti-German, antiItalian, and anti-Japanese (Grill 2003, 32; O'Neill 1993, 129; Fry 2002, 205).

As Weaver suggested, customary racism might have constituted a barrier to fascism. Southern segregationists had no need to adopt newer, more aggressive forms of discrimination since many of the established ones served effectively to suppress African Americans. Southern racism was traditionalist: it was based on the Biblical "curse of Ham" and was not eliminationist as was the Nazi variety. The conservative Democratic senator from North Carolina Josiah W. Bailey opposed Roosevelt's "court packing" in 1937 by claiming that the Supreme Court had protected the South from the evils of "the social equality of the Negro" while prevent- 
ing in America the sort of persecution that Jews faced in Nazi Germany. Virginia senator Carter Glass fought much New Deal legislation and remained a staunch segregationist; yet he became a leader of the interventionist group Fight for Freedom, which formed in early 1941 to promote immediate American entry into the war. According to Southern conservatives, a national government which mandated racial egalitarianism was as "totalitarian" as Communist and fascist states. White Southerners regarded federal encroachment to be as dangerous as an Axis invasion. They fought not for democracy but rather for states' rights (Bailey quoted in Alpers 2003, 80; Ward 2012, 136-140).

Furthermore, the South profited greatly from Washington's defense spending, which—unlike welfare spending-generally reinforced conventional political, economic, and cultural hierarchies. The Roosevelt administration was hesitant to use its leverage to threaten Southern segregation; in return, white Southerners overwhelmingly supported it. Many conservative anti-fascists welcomed increased militarization of society, large defense contracts for big corporations, and continued segregation in the armed forces. Even though American participation in World War II ultimately undermined discrimination against African Americans, Southern participation in the war effort dampened civil-rights protest and reinforced segregation during the war years. ${ }^{2}$ African Americans were incensed by the preferential treatment given to German prisoners of war in establishments which excluded blacks. In the immediate postwar period, conservative Republicans and segregationist Democrats strengthened their hold on Congress and blocked civil-rights legislation (Zelizer 2012, 44). Despite raised expectations, African Americans remained second-class citizens in much of the nation. Nonetheless, by supporting an anti-fascist war, Southerners strengthened the federal government, whose power would eventually eliminate legal racial discrimination.

Southern counterrevolutionary anti-fascism raises a major interpretive issue. Many, if not most, explanations of the failure of fascism in the Western democracies have rested on the liberal-democratic political culture of the US, the UK, and France. Certainly, anti-fascism was especially

\footnotetext{
2 Talk, November 13, 1942, War Policy Division, Box 14, Reuther Library, Detroit.
} 
potent in nations where abolitionism and feminism were the most powerful. Yet the antidemocratic traditions of these nations and their regions also contributed to the domestic and international failures of fascism. As in Spain in the 1930s, in the US too regionalism was typically anti-fascist. The American South's own institutional racism and its lack of secularization presented obstacles to fascism that did not exist in much of Weimar Germany or Northern Italy. Segregationist Protestantism obstructed competing ideologies in the fundamentalist South. Fascist racism did not mean that anti-fascism was not racist.

The growth and toleration, if not encouragement, of regional consciousness among anti-fascists has been underemphasized because of the subsequent collaboration of Flemish, Breton, and Alsatian nationalists during the Nazi occupation of Belgium and France. Yet the anti-fascist tent could also accommodate provincial particularisms. Bretons and other Frenchmen from the Atlantic coast joined the Free French in disproportionally high numbers. In Spain, regional movements in Catalonia and the Basque Country benefited from and contributed to the anti-fascist consensus of the Republican zone in the civil war. During World War II, the Welsh and Scottish fought foreign fascists and largely ignored their anti-English nationalists and pro-German separatists. Much depressed before the war, Scotland-like the American South-profited from a proliferation of government contracts, which led to more than a 250 percent increase in production. Even if a multinational British consciousness began to grow as the anti-fascist left became more sensitive to Scottish and Welsh traditions, a spirit of national unity reached its summit throughout Britain as the conflict endured (Bougeard 2012, 27; Muracciole 2009, 78; Elorza 1998, 114; Calder 1969, 58, 135, 243; Morgan 1998, 207).

\section{Conclusion}

From the Munich Agreement to the fall of France, US counterrevolutionary anti-fascists - who are usually labeled "interventionists" in the historiography-began to articulate in the face of isolationist opposition how fascist regimes, including Franco's Spain, jeopardized US national security in the Atlantic hemisphere. The Nazi invasion of Prague in March 1939, 
which was the first occupation of a non-German sovereign nation, made counterrevolutionary anti-fascists more able to overcome the prevailing Versailles guilt. Christian and Jewish anti-fascists emphasized fascist paganism and its threats to Enlightenment tolerance and traditional religions. Totalitarianism became a concept which attempted to discredit both fascism and communism and linked these states to the rebirth of slavery. The Hitler-Stalin pact reinforced rejection of "totalitarianism" and the identity of both regimes. To combat the "slavery" which characterized both states, anti-fascists, who included both Democrats and Republicans, also authored an abolitionist economic argument that convinced many Americans, especially organized labor, to adopt increasingly pro-Allied postures. Recent immigrants from Italy and Germany demonstrated their adopted nation's assimilationist powers when they and their immediate families rallied to the anti-fascist cause. The fall of the French and Dutch empires led to increased US anxiety over the country's vulnerability in the New World. British resistance to German assault on the UK raised the already high level of Anglophilia. While the white South remained perhaps the most anti-fascist region, interventionists also gained increasing support from African Americans. By the end of 1940, the US would replace France as de facto the UK's major counterrevolutionary anti-fascist ally.

\section{References}

Adamthwaite, Anthony. 1995. Grandeur and Misery: France's Bid for Power in Europe 1914-1940. London: Bloomsbury Academic.

Alpers, Benjamin L. 2003. Dictators, Democracy, and American Public Culture:

Envisioning the Totalitarian Enemy, 1920s-1950s.Chapel Hill, NC: The University of North Carolina Press.

Ascher, Abraham. 2012. Was Hitler a Riddle?: Western Democracies and National Socialism. Stanford: Stanford University Press.

Bell, Leland V. 1970. "The Failure of Nazism in America: The German American Bund, 1936-1941". Political Science Quarterly 85 (4): 585-599.

Bernstein, Arnie. 2013. Swastika Nation: Fritz Kuhn and the Rise and Fall of the GermanAmerican Bund. New York: St. Martin's Press.

Blower, Brooke L. 2014. "From Isolationism to Neutrality: A New Framework for Understanding American Political Culture, 1919-1941”. Diplomatic History 38 (2): 345-376. Doi: https://doi.org/10.1093/dh/dhto91. 
Bosch, Aurora. 2012. Miedo a la democracia: Estados Unidos ante la Segunda República y la Guerra civil española. Barcelona: Crítica.

Bougeard, Christian. 2012. "Eléments d'une approche de l'histoire de la France Libre". In Pour une histoire de la France Libre, edited by Patrick Harismendy and Erwan Le Gall, 15-28. Rennes: Presses Universitaires de Rennes.

Brendon, Piers. 2000. The Dark Valley: A Panorama of the 1930s. New York: Vintage Books.

Calder, Angus. 1969. The People's War: Britain, 1939-1945. New York: Pimlico.

Casey, Steven. 2001. Cautious Crusade: Franklin D. Roosevelt, American Public Opinion, and the War against Nazi Germany. Oxford: Oxford University Press.

Chadwin, Mark Lincoln. 1970. The Warhawks: American Interventionists before Pearl Harbor. New York: W. W. Norton \& Co.

Chalmers, David M. 1965. Hooded Americanism: The History of the Ku Klux Klan. New York: Quadrangle Books.

Cole, Wayne S. 1983. Roosevelt and the Isolationists, 1932-1945. Lincoln, NE: University of Nebraska Press.

Crouter, Richard. 2010. Reinhold Niebuhr: On Politics, Religion, and Christian Faith. New York: Oxford University Press.

Cull, Nicholas J. 1999. "The Munich Crisis and British Propaganda Policy in the United States". In The Munich Crisis, 1938: Prelude to World War II, edited by Igor Lukes and Erik Goldstein, 216-235. London: Routledge.

Deutsch, Bernard S. 1934. "The Disfranchisement of the Jew”. In Pierre van Paassen and James Waterman Wise, eds. Nazism: An Assault on Civilization, 39-58. New York: Harrison Smith and Robert Haas.

Diggins, John P. 1972. Mussolini and Fascism: The View from America. Princeton: Princeton University Press.

Dunn, Susan. 2013. 1940. FDR, Willkie, Lindbergh, Hitler — the Election amid the Storm. New Haven: Yale University Press.

Edwards, Mark Thomas. 2012. The Right of the Protestant Left: God's Totalitarianism. New York: Palgrave Macmillan.

Elorza, Antonio. 1998. "La nation éclatée: Front populaire et question nationale en Espagne”. In Antifascisme et nation: les gauches européennes au temps du Front populaire, edited by Serge Wolikow and Annie Bleton-Ruget, 113-128. Dijon: EUD.

Fox, Richard Wightman. 1985. Reinhold Niebuhr: A Biography. New York: Pantheon.

Fry, Joseph A. 2002. Dixie Looks Abroad: The South and U.S. Foreign Relations, 1789-1973. Baton Rouge, LA: Louisiana State University Press.

Gannon, Franklin Reid. 1971. The British Press and Germany, 1936-1939. Oxford: Clarendon Press.

Gates, Eleanor M. 1981. The End of the Affair: The Collapse of the Anglo-French Alliance, 1939-4o. Berkeley, CA: University of California Press.

Gombin, Richard. 1970. Les socialistes et la guerre: La S.F.I.O. et la politique étrangère française entre les deux guerres mondiales. The Hague: Mouton \& Co. 
Gottlieb, Julie. 2010. "Varieties of Feminist Responses”. In Varieties of Anti-Fascism: Britain in the Inter-War Period, edited by Nigel Copsey and Andrzej Olechnowicz, 101-118. Basingstoke: Palgrave Macmillan.

Grill, Johnpeter Horst. 2003. "The American South and Nazi Racism”. In The Impact of Nazism: New Perspectives on the Third Reich and its Legacy, edited by Alan E. Steinweis and Daniel F. Rogers, 19-38. Lincoln, NE: University of Nebraska Press.

Hamilton, Alice. 1934. “The Enslavement of Women”. In Nazism: An Assault on Civilization, edited by Pierre van Paassen and James Waterman Wise, 76-87. New York: Harrison Smith and Robert Haas.

Harrison, Richard A. 1990. "The United States and Great Britain: Presidential Diplomacy and Alternatives to Appeasement in the 1930s". In Appeasement in Europe: A Reassessment of U.S. Policies, edited by David F. Schmitz and Richard D. Challener, 103-143. New York: Praeger.

Hastings, Max. 2011. Inferno: The World at War, 1939-1945. New York: Alfred A. Knopf. Herman, Arthur. 2012. Freedom's Forge: How American Business Produced Victory in World War II. New York: Random House Trade Paperbacks.

Holmes, John Haynes. 1934. “The Threat to Freedom”. In Nazism: An Assault on Civilization, edited by Pierre van Paassen and James Waterman Wise, 127-142. New York: Harrison Smith and Robert Haas.

Humann, Detlev. 2014. “Die ,Arbeitschlacht" als Krisenüberwindung”. In Arbeit im Nationalsozialismus, edited by Marc Buggeln and Michael Wildt, 71-86. Munich: De Gruyter Oldenbourg.

Inboden, William C. 2014. "The Prophetic Conflict: Reinhold Niebuhr, Christian Realism, and World War II", Diplomatic History 38 (1): 49-82.

Jennings, Eric T. 200o. "La dissidence aux Antilles (1940-1943)", Vingtième Siècle: Revue d'histoire 68: 55-71.

Johns, Richard Seelye. 1946. A History of the American Legion. Indianapolis, IN: The Bobbs-Merrill Co.

Johnstone, Andrew. 2014. Against Immediate Evil: American Internationalists and the Four Freedoms on the Eve of World War II. Ithaca, NY: Cornell University Press.

Jonas, Manfred. 2011. "American Isolationism and the Coming of the Second World War". In The Origins of the Second World War: An International Perspective, edited by Frank McDonough, 229-245. London: Bloomsbury.

Keating, Joan. 1996. "Looking to Europe: Roman Catholics and Christian Democracy in 1930s Britain”. European History Quarterly 26: 57-79.

Lewisohn, Ludwig. 1934. “The Revolt against Civilization”. In Nazism: An Assault on Civilization, edited by Pierre van Paassen and James Waterman Wise, 143-16o. New York: Harrison Smith and Robert Haas.

Lichtenstein, Nelson. 1982. Labor's War at Home: The CIO in World War II. New York: Cambridge University Press.

Lincoln, Mark. 1970. The Warhawks: American Interventionists before Pearl Harbor. New York: W. W. Norton \& Co. 
Lipstadt, Deborah E. 1986. Beyond Belief: The American Press and the Coming of the Holocaust 1933-1945. New York: Touchstone.

Lynch, Cecelia. 1999. Beyond Appeasement: Interpreting Interwar Peace Movements in World Politics. Ithaca, NY: Cornell University Press.

MacDonald, Callum. 1989. "Deterrent Diplomacy: Roosevelt and the Containment of Germany, 1938-1940". In Paths to War: New Essays on the Origins of the Second World War, edited by Robert Boyce and Esmonde M. Robertson, 297-329. New York: Palgrave Macmillan.

MacLean, Nancy. 1995. Behind the Mask of Chivalry: The Making of the Second Ku Klux Klan. Oxford: Oxford University Press.

Mayer, Arno J. 1971. Dynamics of Counterrevolution in Europe, 1870-1956: An Analytic Framework. New York: Harper and Row.

Mayers, David. 2013. FDR's Ambassadors and the Diplomacy of Crisis. New York: Cambridge University Press.

McKercher, B. J. C. 1999. Transition of Power: Britain's Loss of Global Pre-Eminence to the United States, 1930-1945. New York: Cambridge University Press.

Meisel, James H. 1966. Counter-Revolution: How Revolutions Die. New York: Atherton Press.

Moore, Michaela Hoenicke. 2010. Know Your Enemy: The American Debate on Nazism, 1933-1945. New York: Cambridge University Press.

Morgan, Kevin. 1998. "Une toute petite différence entre La Marseillaise et God Save the King: La gauche britannique et le problème de la nation dans les années trente”. In Antifascisme et nation: les gauches européennes au temps du Front populaire, edited by Serge Wolikow and Annie Bleton-Ruget, 203-212. Dijon: EUD.

Muracciole, Jean-François. 2009. Les Français libres: L’autre Résistance. Paris: Editions Tallandier.

Offner, Arnold A. 1975. The Origins of the Second World War. New York: International Thomson Publishing.

Olson, Lynne. 2010. Citizens of London: The Americans Who Stood with Britain in Its Darkest, Finest Hour. New York: Random House Trade Paperback.

- 2013. Those Angry Days: Roosevelt, Lindbergh, and America's Fight over World War II, 1939-1941. New York: Random House Trade Paperbacks.

O’Neill, William L. 1993. A Democracy at War: America's Fight at Home and Abroad in World War II. New York: Harvard University Press.

Ovendale, Ritchie. 1989. "Why the British Dominions declared War". In Paths to War: New Essays on the Origins of the Second World War, edited by Robert Boyce and Esmonde M. Robertson, 269-296. New York: Palgrave Macmillan.

Paxton, Robert O. 2004. The Anatomy of Fascism. New York: Alfred A. Knopf.

Plummer, Brenda Gayle. 1996. Rising Wind: Black Americans and U.S. Foreign Affairs, 1935-196o. Chapel Hill, NC: The University of North Carolina Press.

Reynolds, David. 1990. “1940: Fulcrum of the Twentieth Century?”. International Affairs 66 (2): 325-350. 
Sanders, Marion K. 1973. Dorothy Thompson: A Legend in Her Time. Boston: Houghton Mifflin.

Schmitz, David F. 1990. “'Speaking the Same Language': The U.S. Response to the ItaloEthiopian War and the Origins of American Appeasement”. In Appeasement in Europe: A Reassessment of U.S. Policies, edited by David F. Schmitz and Richard D. Challener, 75-102. New York: Praeger.

Sparrow, James T. 2011. Warfare State: World War II, Americans, and the Age of Big Government. New York: Oxford University Press.

Steiner, Zara. 2011. The Triumph of the Dark: European International History, 1933-1939. Oxford: Oxford University Press.

Strachan, Hew. 1997. "The Soldier's Experience in Two World Wars: Some Historiographic Comparisons". In Time to Kill: The Soldier's Experience of War in the West, 1939-1945, edited by Paul Addison and Angus Calder, 369-378. London: Pimlico.

Thomas, Martin. 1996. Britain, France and Appeasement: Anglo-French Relations in the Popular Front Era. London: Bloomsbury.

Thompson, Dorothy. 1934. "The Record of Persecution”. In Nazism: An Assault on Civilization, edited by Pierre van Paassen and James Waterman Wise, 1-24. New York: Harrison Smith and Robert Haas.

Tierney, Dominic. 2007. FDR and the Spanish Civil War: Neutrality and Commitment in the Struggle that Divided America. Durham, NC: Duke University Press.

Trubowitz, Peter. 2011. Politics and Strategy: Partisan Ambition and American Statecraft. Princeton: Princeton University Press.

Tuttle, Charles H. 1934. “The American Reaction”. In Nazism: An Assault on Civilization, edited by Pierre van Paassen and James Waterman Wise, 250-256. New York: Harrison Smith and Robert Haas.

Vieth, Jane Karoline. 1990. "Munich and American Appeasement". In Appeasement in Europe: A Reassessment of U.S. Policies, edited by David F. Schmitz and Richard D. Challener, 51-74. New York: Praeger.

Wapshott, Nicholas. 2015. The Sphinx: Franklin Roosevelt, the Isolationists, and the Road to World War II. New York: W. W. Norton \& Co.

Ward, Jason Morgan. 2012. “A War for States' Rights”. In Fog of War: The Second World War and the Civil Rights Movement, edited by Kevin M. Kruse and Stephen Tuck, 126144. New York: Oxford University Press.

Winkler, Heinrich August. 2015. The Age of Catastrophe: A History of the West, 1914-1945. Translated by Stewart Spencer. New Haven: Yale University Press.

Wise, James Waterman. 1934a. “Introduction”. In Nazism: An Assault on Civilization, edited by Pierre van Paassen and James Waterman Wise, ix-xii. New York: Harrison Smith and Robert Haas.

Wise, Stephen S. 1934b. “The War upon World Jewry”. In Nazism: An Assault on Civilization, edited by James Waterman Wise and Pierre van Paassen, 202-211. New York: Harrison Smith and Robert Haas. 
Whiting, Cécile. 1989. Antifascism in American Art. New Haven, CT: Yale University Press.

Zelizer, Julian E. 2012. "Confronting the Roadblock: Congress, Civil Rights, and World War II". In Fog of War: The Second World War and the Civil Rights Movement, edited by Kevin M. Kruse and Stephen Tuck, 32-50. New York: Oxford University Press.

Zietsma, David. 2007. "Sin Has No History: Religion, National Identity, and U.S. Intervention, 1937-1941” Diplomatic History 31 (3): 531-565.

\section{Archives and Periodicals}

Catholic World

Reuther Library, Detroit

Washington Post 